\section{Analysis of influencing factors of burden of caregiver among stroke patients at home}

\author{
Nikmatul Fadilah, ${ }^{1,2}$ Kusnanto, ${ }^{3}$ \\ Nursalam, ${ }^{3}$ Loetfia Dwi Rahariyani ${ }^{2}$ \\ ${ }^{1}$ Doctoral Program of Public Health, \\ Faculty of Public Health, Universitas \\ Airlangga; ${ }^{2}$ Polytechnic of Health, \\ Ministry of Health, Surabaya; ${ }^{3}$ Faculty \\ of Nursing, Universitas Airlangga, \\ Indonesia
}

\begin{abstract}
The role of families in providing care for stroke patients at home can cause ongoing stress, and can be a burden to caregivers. The purpose of this study was to analyze the influence of factors of age, sex, education, employment, family relationship, length of care, duration of care, health problems of caregiver, and deficit neurology of stroke on the burden of caregivers. Study used analytical design through cross sectional approach. Samples of 120 caregivers were taken in 2 Puskesmas namely Pegirian and Pucang Sewu in Surabaya City with simple random sampling technique. Research instruments in the form of questionnaires compiled by researchers. Multiple linear regression used to analyze the influence of several factors on the burden of caregiver among stroke patients. The results of the t-test can be concluded that there is no partial effect on age, gender, family relationship, education, employment, length of care, health problems of caregivers, and deficit neurology of stroke on the burden of caregiver among stroke patients, and only the duration of care is influential against the burden of caregiver among stroke patients ( $\mathrm{p}$ value $0.001)$.
\end{abstract}

\section{Introduction}

The family is a unit that has an important and major role in health care in the community, including the function to maintain health (health care function) for family members who suffer from an illness. The role of the family in maintaining the health of family members is needed especially in the treatment of chronic diseases including non-communicable diseases which currently tend to increase in prevalence both in urban and rural areas, including strokes.

Changes in conditions experienced by stroke patients, especially the existence of disability can cause them to experience obstacles in the activities of daily living, and some of them experience dependence in living their lives, even stating that the quality of their lives decreases. ${ }^{1,2}$ Stressors are also considered high for stroke patients and their families, namely changes in the family economy by a percentage of $100 \%{ }^{3,4}$ Continuous stressors in stroke patients and care providers will continue to be a strain and burden for both physical / health, emotional, social and financial burdens. ${ }^{5-8}$ The high burden felt by the caregiver is manifested as symptoms of anxiety, depression, and low physical health.7,9 Caregivers and stroke patients who experience strains and burden during acute phase care in hospitals and rehabilitation phases at home, say they are not ready to provide care, live dissatisfaction (interpersonal and marital relationships), lack of well-being, and quality deterioration live both. 1,10

Caregivers' families should also receive attention and support for their needs from health care providers, so that they remain in the best condition to still be able to provide support and care for family members who have had a stroke, both informational support; emotional; instrumental; and appreciation, and avoid the burden of caregiver situation. ${ }^{11,12}$

Interventions during the rehabilitation phase in the form of therapeutic counseling, psycho-education, skills training are alternative interventions that are proven to reduce the burden of care, increase satisfaction, well-being, and quality of life of care givers. ${ }^{5,13}$ This therapy is expected to help families especially care givers to be able to resolve problems (care load) when caring for sick family members immediately, provide motivation and change the behavior of care givers, and ultimately caregivers can carry out adaptive coping strategies. ${ }^{14}$ Family coping and/or effective/adaptive care providers will bring families to achieve a family resilience and feel a satisfying, prosperous, and quality life. ${ }^{15}$ The purpose of this study was to analyze the influence of factors of age, sex, education, occupation, family relationship, length of care, duration of care, health care provider problems, and deficit neurology of stroke on the burden of care givers.

\section{Materials and Methods}

Study used analytical design through cross sectional approach. Variables in this study included burden of caregiver and its influencing factors. Samples of 120 caregivers were taken in 2 Puskesmas namely Pegirian and Pucang Sewu in Surabaya City
Correspondence: Nikmatul Fadilah, Doctoral Program of Public Health, Faculty of Public Health, Universitas Airlangga, Jl. Mulyorejo, Surabaya, Jawa Timur 60115, Indonesia. Tel: +62315920948 - Fax: +62315924618 Email: nikmatul.fadilah-

2017@fkm.unair.ac.id.

Key words: burden, caregivers, stroke patients.

Contributions: NF and LDR participated in design of study, data collecting and analyzing; $\mathrm{NF}, \mathrm{K}, \mathrm{N}$ participated in manuscript writing and references search.

Conflict of interests: the authors declare no potential conflict of interests.

Funding: the work was supported by Polytechnic of Health-Ministry of Health of Surabaya grant.

Conference presentation: part of this paper was presented at the 3rd International Symposium of Public Health, 2018 October 31- November 1, Universitas Airlangga, Surabaya, Indonesia.

Acknowledgment: the authors would like to thank to the Director of Polytechnic of Health, Ministry of Health, Surabaya, Indonesia.

Dedication: the article is dedicated to Doctoral Program of Public Health, Faculty of Public Health, Universitas Airlangga, Surabaya, Indonesia; and Polytechnic of Health, Ministry of Health, Surabaya, Indonesia.

Received for publication: 28 July 2019. Revision received: 9 September 2019. Accepted for publication: 15 October 2019.

This work is licensed under a Creative Commons Attribution NonCommercial 4.0 License (CC BY-NC 4.0).

${ }^{\circ}$ Copyright: the Author(s), 2019

Licensee PAGEPress, Italy

Journal of Public Health in Africa 2019; 10(s1):1188 doi:10.4081/jphia.2019.1188

with simple random sampling technique. Research instruments in the form of questionnaires compiled by researchers. Multiple linear regresion used to analyze the influence of several factors on the burden of caregiver among stroke patients. Ethical approval letter was gained from the Health Research Ethics commission of of Health, Ministryof Health, Surabaya number: 194/S/KEPK/V/2018 at 8th June 2018. 


\section{Results}

This study showed several factors on the burden of caregiver among stroke patients based on frequency distribution, $\mathrm{R}$ square, F-value/Anova and T-test analysis.

Table 1 shows that the highest caregiver burden is 10 , the care provider of stroke patients is based on the highest age 52 years (early elderly), the highest gender is women, the highest education is high school, the status is not working / housewives, the most family relationships as a wife, long caring for patients Most strokes are 1 year, the duration of treatment is 2 hours a day, there are no health problems, and most stroke patients have deficit neurology of stroke (Table 2).

The $\mathrm{R}$ square value of $0.146(14.6 \%)$ shows that $14.6 \%$ variants of stroke care costs for stroke patients are affected by nine independent variables (age, sex, family relationship, education, employment, length of care, duration of care, health problems at home care givers, and deficit neurology of stroke); while the remaining $82.2 \%$ is influenced by other factors outside the model (other factors besides 9 variables in the model). $\mathrm{R}$ value is 0.382 , which means that the factors are age, gender, family relationship, education, occupation, length of treatment, duration of care, health problems of home care givers, and deficit neurology of stroke have a moderate effect on the burden of care givers (Table 3 ).

The test results of F sig $1.328(>0.05)$, then the conclusion there is no influence together with age, gender, family relationship, education, employment, length of care, duration of care, health problems of home care givers, and deficit neurology of stroke on caregiver burden (Table 4).

The results of the t-test can be concluded that there is no partial effect on age, gender, family relationship, education, occupation, length of care, health care problems of home caregivers, and deficit neurology of stroke on the burden of the care of stroke patients, and only the duration of treatment that affects the burden care provider for stroke patients.

\section{Discussion}

Factors of age, sex, family relationship, education, employment, length of care, health problems at home care givers, and deficit neurology of stroke did not affect the burden of caregivers of stroke patients, and only the duration of treatment which affected the caregiver burden of stroke patients. The strain and burden experienced by caregivers is influenced by gender (women); age (elderly); low education); employment (retired); hours of care provided; and mental health, while factors affecting stroke patients are physical disorders / weaknesses in motor and cognitive function of stroke patients; depressive symptoms; decreased verbal ability; walking difficulties and neurological deficits. . $^{9} 11,16$

The caregivers reported that burden of caring among stroke patients highest was physical burden, this condition is related to the duration of routine treatment, which is 2 hours / day. The condition of stroke patients who have residual symptoms, especially stiffness / weakness / limb paralysis con-

tributes to the patient's degree of dependence which ultimately adds to the burden of physical care for the care provider of stroke patients at home. Symptoms of residual on stroke patients in this study include rigidity, weakness, and / or extremity paralysis. The age factor can also increase the level of dependence of stroke patients that have an impact on the burden of care. The highest age of stroke patients was in the elderly group (46-65 years), even some included the elderly category ( $\geq 65$ years). The physiologically aging process of the neuromuscular system will reduce the physiological function of the limbs, especially the extrem-

Table 1. Variable Frequency Distribution.

\begin{tabular}{lccccccc}
\hline No & Variable $(\mathrm{n}=120)$ & Mode & Median & Mean & SD & Min & Max \\
1 & Caregiver burden & 10 & 24 & 23.31 & 12.342 & 1 & 59 \\
2 & Age & 52 & 48 & 45.94 & 12.239 & 19 & 72 \\
\hline 3 & Gender & 2 & 2.00 & 1.73 & 0.444 & 1 & 2 \\
4 & Family relationship & 2 & 2.00 & 2.32 & 0.860 & 1 & 4 \\
\hline 5 & Education & 3 & 2.00 & 2.10 & 1.198 & 0 & 5 \\
6 & Employment & 0 & 2.00 & 1.81 & 1.826 & 0 & 5 \\
\hline 7 & Length of care & 1 & 1.00 & 1.863 & 2.201 & 0 & 18 \\
8 & Duration of caring & 2 & 2.00 & 2.98 & 2.558 & 0 & 12 \\
\hline 9 & Health problem & 0 & 1.00 & 1.34 & 1.332 & 0 & 5 \\
10 & Deficit neurology of stroke & 2 & 2.00 & 2.26 & 1.470 & 0 & 7 \\
\hline
\end{tabular}

Table 2. Table R square.

\begin{tabular}{ccccc} 
Model & $\mathbf{R}$ & R Square & Adjusted R Square & Std. Error of the Estimate \\
1 & $.369 \mathrm{a}$ & .136 & .065 & 11.932 \\
\hline
\end{tabular}

Table 3. Table F-value/Anova.

\begin{tabular}{lcccc} 
Model & Sum of Squares & df & Mean Square & F \\
Regression & 2467.334 & 9 & 274.148 & 1.926 \\
Residual & 15660.258 & 110 & 142.366 & \\
\hline Total & 18127.592 & 119 & & \\
\hline
\end{tabular}

Table 4. T-test value.

\begin{tabular}{|c|c|c|c|c|c|c|}
\hline \multirow{2}{*}{\multicolumn{2}{|c|}{ No Variable }} & \multicolumn{2}{|c|}{$\begin{array}{l}\text { Unstandardized } \\
\text { Coefficients }\end{array}$} & \multirow{2}{*}{$\begin{array}{c}\text { Standardized } \\
\text { Coefficients } \\
\text { Beta }\end{array}$} & \multirow[t]{2}{*}{$t$} & \multirow[t]{2}{*}{ Sig. } \\
\hline & & B & Std. Error & & & \\
\hline 1 & (Constant) & 25.123 & 9.587 & & 2.621 & 0.010 \\
\hline 2 & Age & -0.039 & 0.111 & -0.038 & -0.346 & 0.730 \\
\hline 3 & Gender & 0.715 & 2.956 & 0.026 & 0.242 & 0.809 \\
\hline 4 & Family relationship & -2.265 & 1.487 & -0.158 & -1.524 & 0.130 \\
\hline 5 & Education & -0.236 & 1.103 & -0.023 & -0.214 & 0.831 \\
\hline 6 & Employment & -0.378 & 0.655 & -0.056 & -0.577 & 0.565 \\
\hline 7 & Long of caring & 0.057 & 0.512 & 0.010 & 0.112 & 0.911 \\
\hline 8 & Duration of caring & 1.494 & 0.453 & 0.310 & 3.296 & 0.001 \\
\hline 9 & Health problem & -0.122 & 0.917 & -0.013 & -0.133 & 0.895 \\
\hline 10 & Deficit neurology of stroke & 0.334 & 0.785 & 0.040 & 0.425 & 0.671 \\
\hline
\end{tabular}


ities, including decreased ADL ability. ${ }^{17}$

The care provider for stroke patients feels stress due to stoke attacks on their family members since the acute care period in the hospital / health care facility and the advanced treatment phase at home. Stressors during the rehabilitation period are often linked to the needs of the patient for physical assistance to fulfill their needs. ${ }^{1,2}$ The highest age of care providers for stroke patients is the category of early elderly (46-55 years) and female gender, most of which are the wives of patients. Based from the education of high school care providers and some only elementary school education. Most caregivers did not work (housewives), and some of them said that since their husbands were sick they tried to find additional income by entrepreneurship / selling at home. The burden of care was felt to be especially hard during the initial period of home care, which was around one to two years at home. Most caregivers said that they had treated a family member who suffered a stroke for 1 year, with the most duration of treatment for 2 hours.

Health problems that are also experienced by caregivers of stroke patients can affect the perceived care burden of care for stroke patients, but in this study most had no health problems. Three major health problems reported to care for stroke patients in this study were fatigue, suffering from certain diseases, and irritability. This condition is in line with previous studies that the high burden felt by the caregiver (burden of caregiver) is manifested in the form of symptoms of anxiety, depression, and low physical health. ${ }^{7,9}$ Some diseases that also affect caregivers of stroke patients include hypertension, diabetes mellitus, gastritis, hypercholesterolemia, and hyperuricemia. ${ }^{7,9,15}$ Some of these diseases (hypertension, diabetes mellitus, hypercholesterolemia) are included in the non-communicable disease category which should require management of regular and continuous / long-term therapy and treatment to avoid complications including stroke. Care givers tend to ignore the health problems they experience while caring for family members with strokes. ${ }^{18}$ Although care providers feel the burden of caring for family members with strokes who need help both physically and emotionally, they state that caring for sick family members, especially husband/wife and parents is a role responsibility that must be lived with sincerity as a form of devotion to husband/wife or parents. This statement is a value/belief that is adhered to and influenced by a familial culture in the majority of the country's population in Asia (Hong Kong) and a value system based on religion/religion that directs caring for sick family members, especially the elderly, to serve younger family members to members older families, especially parents, as well as the wife's service to her husband/partner. ${ }^{9}$

Caregivers of stroke patients have an important role in maintaining the health of families with stroke and other family members, especially if they act as mothers. Care providers and / or families of stroke patients need intervention to overcome the crisis situation due to stroke. Although some studies did not mention/conclude which therapies proved to be the most effective, some experts mentioned 3 interventions that had the effect of reducing the burden of mild to moderate care, namely psycho-education, therapy, and supportive. ${ }^{9,18}$ Nurses as health professionals who play a major role in public health care activities including families with strokes need to develop modification of interventions that support families, especially caregivers who remain in optimal health and show coping behaviors effective in overcoming crisis conditions due to stroke in family members.

\section{Conclusions}

Only the factor of duration of treatment each day that affects the burden of care, while the factors of age, gender, family relationships, education, employment, length of care, health problems of home care givers, and deficit neurology of stroke are not affected.

Modification of services through the implementation of community health programs through individual health efforts for stroke patients in primary health care (Puskesmas) buildings and at home (home visits), as well as group services for families who provide care in groups and at home through home visits can be a comprehensive effort.

\section{References}

1. Handayani DY, Dewi DE. Analisis kualitas hidup pasien dan eluarga pasca serangan stroke (dengan gejala sisa). Psycho Idea 2009;7(1):35-44. Available from: http://jurnalnasional.umj.ac.id. Accessed on: 12 January 2018.

2. Ogunlana MO, Dada OO, Oyewo OS, et al. Quality of life \& burden of informal caregiver of stroke survivor. Hong Kong Physioherapy Journal 2014;32:6-12. Available from: http://www.sceincedirect.com. Accessed on: 12 January 2018.
3. Hariyati RTS, Sumarwati M, Handayani H. Pengaruh manajemen stres terhadap kesiapan pasien stroke dan keluarga dalam merencanakan perilaku adaptif pasca perawatan di rumah sakit. Jurnal Keperawatan Indonesia 2004;8(1). Available from: http://www.jkiui.ac.id. Accessed on: 11 January 2018.

4. Pambudi HA. Studi fenomenologis: kecemasan keluarga pada pasien stroke yang dirawat di ruang HND Santo Lukas RS St. Elisabeth Semarang. Diponegoro University Institutional Repository 2009. Available from: http://eprints.unpad.ac.id. Accessed on: 3 March 2018

5. Collins L, Swartz K. Caregiver care. American family physician 2011;83:1309-1317. Available from: http://www.aafp.org. Accessed on: 3 May 2018.

6. Gbiri CA, Olawela OA, Isacc SO. Stroke management: informal caregivers burdens and strain of caring for stroke survivors. Annals of Physical and Rehabilitation Medicine 2015;58:98-103.

7. Kumar R, Kaur S, Reddemma K. Burden and coping strategies in caregivers of stroke survivor. Journal of neurology and neuroscience 2015;S1:15. Available from: https://doi.org/ 10.21767/2171-6625.S10005. Accessed on: 2 April 2018.

8. Vincent C, Derosiers J, Landreville P, et al. Burden of caregiver of people with stroke: evolution and predictors. Cerebrovascular Disease 2009;2:456464.

9. Chow SKY, Wong FKY, Poon C. Coping and caring: support for family caregivers of stroke survivor. Journal of Clinical Nursing 2007;16:133-143.

10. Mc Pherson CJ, Wilson KG, Chyurlia $\mathrm{L}$, et al. The balance of give and take in caregiver partner relationships: an examination of self-perceived burden, relationships equity, and QoL from perspective of care recipients following stroke. Rehabilitation Psychology 2010;55:194-203.

11. Vincent C, Derosiers J, Landreville P, et al. Burden of caregiver of people with stroke: evolution and predictors. Cerebrovascular Disease 2009;2:456464.

12. Wurtiningsih R. Dukungan keluarga pada pasien stroke di ruang saraf RSUD dr. Kariadi Semarang. Medica Hospitalia 2012;1:57-59.

13. Bjorh-dahl A, Nilsson AL, Sunnerhagen KS. Can rehabilitation in the home setting reduce the burden of caregiver for the next-of-kin of stroke victims?. J 
Rehabil Med 2007;39:27-32.

14. Hernawaty T. 2015. Modul terapi supportif keluarga: pada keluarga dengan klien gangguan jiwa. Workshop Keperawatan Jiwa ke-IX, Depok, 25 Agustus 2015. Program Studi Ners Spesialis I Keperawatan Jiwa. Fakultas Ilmu Keperawatan Universitas Indonesia.

15. Fadilah N, Kusnanto K, Nursalam N, et al. Structural Models of Factor Relating to The Family Resilience of Patients with Stroke. Indian Journal of Public Health Research and Development 2018;9(11):194-199. Available from: http://dx.doi.org/10.5958/09765506.2018.01721.7. Accessed on: 3 January 2019.

16. Rigby H, Gubitz G, Phillips S. A systematic review caregiver burden following stroke. International Journal of Stroke 2009;4:285-292.
17. Smeltzer SC, Bare BG. Brunner \& Suddarth: Keperawatan Medikal Bedah. Edisi 8 Volume 2. Jakarta: Penerbit Buku Kedokteran EGC;2013.

18. Bakas T, Clark PC, Kelly-Hayes M, et al. Evidence for stroke family caregiver and dyad intervention: a statement for healthcare professionals from the American Heart Association and American Stroke Association. Stroke 2014;45:2836-2852. 